\title{
Analisis Kuat Tekan Beton Dengan Penambahan Serat Rooving Pada Beton Non Pasir
}

\author{
${ }^{\square}$ Aris Widodo ${ }^{1}$, Muhammad Abdil Basith ${ }^{2}$ \\ 1,2 Jurusan Teknik Sipil, Fakultas Teknik, Universitas Negeri Semarang (UNNES)
}

\section{Kata Kunci/ Keywords :}

roving fiber, compressive strength, tensile strength.

serat roving, kuat tekan, kuat tarik belah.

\begin{abstract}
Abstrak:
This study aims to determine the effect of adding roving fiber on nonsand concrete to compressive strength and tensile strength. The test specimens used in this study, for each type of variable are 3 cylinders of compression test. The ratio of the volume of mortar is 1: 5 (cement: gravel) while the roving fiber used is $3 \mathrm{~cm}$ in length. the addition of roving fibers of each mixture of $0 \%, 2.5 \%, 5 \%, 7.5 \%, 10 \%$ were taken from the weight of the cement. From the results of the research it is found that the addition of roving fiber can increase the compressive strength of non-sand concrete. With the addition of compressive strength concrete roving with an aggregate ratio of $1: 5$, it is optimal on the percentage of roving fiber addition of $5 \%$.
\end{abstract}

Penelitian ini bertujuan untuk mengetahui pengaruh penambahan serat roving pada beton non pasir terhadap kuat tekan dan kuat tarik belahnya. Hasil penelitian ini diharapkan menjadi masukan bagi khalayak umum khususnya bagi industri bahan bangunan, dan dapat bermanfaat untuk peneliti-peneliti selanjutnya. Benda uji yang digunakan dlam penelitian ini, untuk masingmasing jenis variable berupa 3 silinder uji tekan. Perbandingan volume adukan adalah 1:5 (semen:kerikil) sedang serat roving yang digunakan panjangnya 3 $\mathrm{cm}$. Penambahan serat roving masing-masing adukan sebanyak $0 \%, 2.5 \%$, $5 \%, 7.5 \%, 10 \%$ diambil dari berat semen. Dari hasil penelitian didapat bahwa penambahan serat roving dapat meningkatkan kuat tekan beton non pasir. Dengan penambahan serat roving kuat tekan beton dengan perbandingan agregat $1: 5$, optimal pada persentase penambahan serat roving sebesar $5 \%$.

Sitasi:

Widodo, Aris (2017). Analisis Kuat Tekan Beton Dengan Penambahan Serat Rooving Pada Beton Non Pasir. J urnal Teknik Sipil \& Perencanaan, 19(2), 115120.

(C) 2017 Universitas Negeri Semarang

\footnotetext{
Aris Widodo:

Gedung E4, Kampus Sekaran

Universitas Negeri Semarang, Kota Semarang

E-mail : ariswidodo71@yahoo.co.id
} 


\section{PENDAHULUAN}

Beton merupakan suatu konstruksi yang umumnya tersusun dari air semen dan agregat. Penggunaan beton saat ini tidak hanya pada ruang lingkup struktur saja, akan tetapi bisa juga digunakan untuk non struktur. Banyak komponen non struktur bangunan yang terbuat dari beton misalnya, dinding, kolom praktis, perabot rumah, maupun berbagai macam hiasan. Penggunaan beton pada komponen non struktur tentulah berbeda dengan struktur dimana komposisi di desain sedemikian rupa untuk menghasilkan beton dengan nilai estetika maupun dari segi ekonomi yang lebih.

Salah satu produk beton untuk penggunaan non struktur dan struktur ringan ialah beton non pasir (no fines concrete). Komposisi yang mengabaikan agregat halus dalam pembuatannya dapat mengurangi berat jenis beton tersebut. Selain itu, tidak adanya agregat halus dapat menimbulkan porositas pada beton tersebut yang diakibatkan oleh rongga yang tidak terisi oleh material yang lebih kecil.

Porositas yang tinggi pada beton non pasir sangat tidak memungkinkan penggunaan baja tulangan untuk menahan gaya tarik. Hal ini disebabkan oleh kelemahan material baja terhadap korosi yang ditimbulkan oleh proses oksidasi air yang masuk pada celah ruang kosong (porous) beton non pasir. Salah satu usaha untuk mengatasi hal ini adalah dengan mengganti tulangan baja sebagai material penahan kuat tarik pada komponen komposit beton dengan bahan serat sintetis. Salah satu yang bisa digunakan sebagai pengganti baja tulangan adalah serat roving.

Serat roving merupakan salah satu bahan yang mudah didapat dan harganya cukup murah. Serat ini banyak digunakan pada industri pembuatan gypsum, serat roving mempunyai ketahanan terhadap bahan kimia, permukaannya kedap air sehingga mencegah terjadinya penggumpalan serat selama proses pengadukan. Dalam hal ini penggunaan serat roving sebagai pengganti baja tulangan pada beton non pasir bisa menambah kuat tarik.

Pada penelitian ini perencanaan campuran beton non pasir menggunakan perbandingan semen banding agregat kasar 1:5, dengan Faktor Air Semen (FAS) 0,4. Untuk konsentrasi serat roving panjang $3 \mathrm{~cm}$ yang digunakan adalah : $0 \%$, $2,5 \%, 5 \%, 7,5 \%$, dan $10 \%$ diambil dari berat semen. Semen yang digunakan ialah semen PCC merek Holcim yang banyak digunakan dipasaran. Agregat kasar yang digunakan adalah agregat dari kali garang dengan butir maksimal $20 \mathrm{~mm}$ yang mempunyai permukaan alami.
Maksud dan tujuan dari penelitian ini adalah untuk mengetahui besar kadar serat yang dapat dihasilkan kuat tekan beton non pasir yang optimal.

\section{Beton Non Pasir}

Menurut Diarto (2014), beton non pasir adalah bentuk sederhana dari beton ringan yang dibuat dengan cara mengurangi penggunaan butiran halus (pasir). Menurut Kardiyono (2007), beton non pasir (no fines concrete) ialah bentuk sederhana dari jenis beton ringan yang dalam pembuatannya tidak dengan agregat halus. Tidak digunakannya agregat halus dalam komposisi beton ini menyebabkan berkurangnya berat jenis beton tersebut. Hal ini dikarenakan munculnya pori pada beton tersebut yang bisa mencapai $20-25$ persen. Kelebihan utama dari pemakaian beton non pasir ini adalah:

1. Lebih bersifat isolasi panas

2. Cara pembuatannya yang lebih cepat dan sederhana

3. Bobotnya yang ringan

4. Susutnya yang hanya sedikit

5. Tidak ada kecenderungan untuk bersegregasi sehingga dapat di jatuhkan dengan tinggi jatuh yang lebih tinggi

6. Kebutuhan semen sedikit (karena tidak ada pasir, maka luas permukaan butir agregat berkurang sehingga kebutuhan semen hanya sedikit)

7. Mudah meloloskan air

Porositas pada beton non pasir mengakibatkan kekuatan beton tersebut berkurang. Selain itu, hal ini juga menyebabkan tidak memungkinkannya penggunaan baja tulangan sebagai bahan komposit beton non pasir karena akan memicu percepatan korosi pada baja tersebut.

Berat jenis beton non-pasir dipengaruhi oleh gradasi agregat yang dipakai dan berkisar antara $60-75 \%$ dari beton biasa. Agregat kasar yang dipakai pada umumnya berukuran $10 \mathrm{~mm}$ sampai $20 \mathrm{~mm}$. Pemakaian agregat dengan gradasi rapat dan permukaan yang tajam (batu pecah) akan menghasilkan beton non-pasir dengan kuat tekan dan berat jenisnya sedikit lebih tinggi daripada memakai agregat seragam dan bulat (kerikil).

Faktor air semen pada beton non-pasir tidak terlalu besar berkisar antara 0,36 sampai 0,46 karena jika faktor air semen terlalu rendah maka pasta semennya tidak akan cukup untuk menyelimuti permukaan dari agregat kasarnya, sedangkan jika faktor air semen terlalu tinggi maka pasta semen akan terlalu encer sehingga pada saat pemadatan pasta semen akan mengendap di bagian bawah. 
Hasil penelitian Kardiyono (1992) dalam Kardiyono 2007 yang membuat beton non pasir dari pecahan genteng keramik diperoleh nilai faktor air semen optimum sekitar 0,40 dengan kuat tekan antara $5 \mathrm{MPa}$ sampai $10 \mathrm{MPa}$ untuk perbandingan volume agregat semen 10 sampai 6 . Sedangkan hasil penelitian Akhmad Subhannur (2002) dalam Kardiyono 2007 yang menggunakan kerikil dari gunung Merapi menunjukkan bahwa kuat tekan sebesar $18 \mathrm{MPa}$ jika rasio volume agregat semen 4 dan sebesar $4 \mathrm{MPa}$ jika rasio volume agregat semen 10 dengan faktor air semen konstan sebesar 0,40 .

Karena kuat tekannya yang relatif rendah maka sampai saat ini beton non-pasir hanya dipakai untuk bagian non-struktur, misalnya bata beton atau dinding tembok, namun kadang-kadang dipakai pula untuk bagian struktur ringan (rumah sederhana).

\section{Beton Serat}

Beton serat merupakan campuran beton ditambah serat, umumnya berupa batangbatang dengan ukuran $5-500 \mathrm{~m}$, dengan panjang sekitar $25 \mathrm{~mm}$. Bahan serat dapat berupa serat asbestos, serat plastik (polypropylene), atau potongan kawat baja. Kelemahannya sulit dikerjakan, namun lebih banyak kelebihannya antara lain kemungkinan terjadi segregasi kecil, daktail, dan tahan benturan (Mulyono, 2005:309).

Penggunaan serat pada beton serat saat ini sudah sangat berkembang. Hal ini ditandai dengan munculnya inovasi-inovasi baru penggunaan serat alami dan sintetis pada beton.

Serat dari bahan alami seperti serat tumbuhtumbuhan, ijuk, bambu, dan sabut kelapa dapat dipakai untuk beton non-struktural. Keuntungan dengan penulangan serat adalah dapat mencegah retakan beton yang terlalu dini, baik akibat panas hidrasi maupun akibat pembebanan. Selain itu, tahan terehadap kerusakan pada beton yang mempunyai tingkat porositas tinggi.

Dalam penelitian yang dilakukan oleh Sarjono \& Wahjono (2008) menghasilkan grafik sebagai berikut:

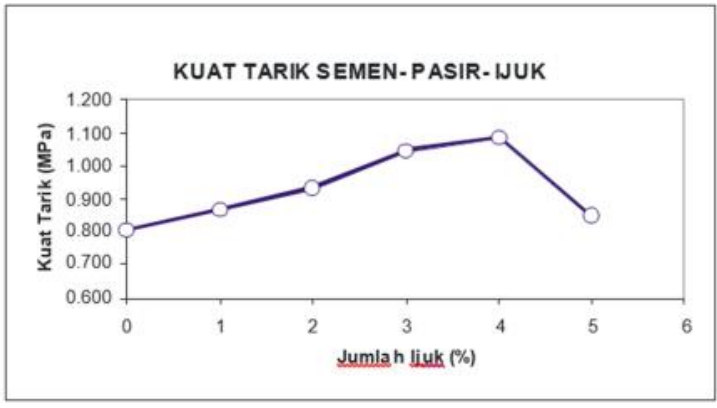

Gambar 1. Grafik hubungan kuat tarik campuran semen-pasir-ijuk dengan persentase penambahan ijuk (Sarjono \& Wahjono, 2008)

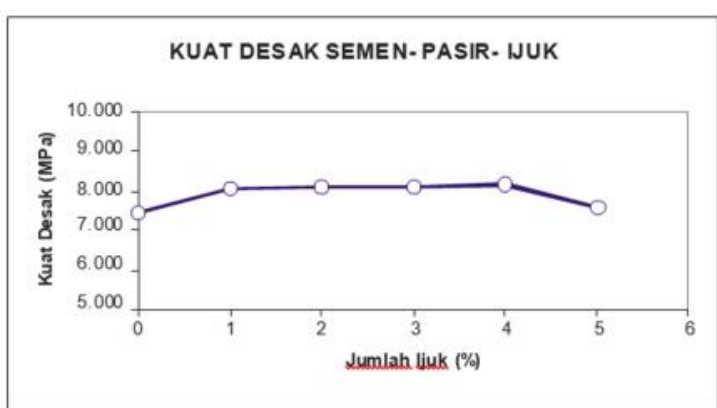

Gambar 2. Grafik hubungan kuat desak campuran semen-pasir-ijuk dengan persentase penambahan ijuk (Sarjono \& Wahjono, 2008)

Perbandingan (volume) adukan adalah 1 : 11 (semen : pasir) sedang serat ijuk yang digunakan dengan panjang 2,5 cm. Penambahan serat ijuk masing- masing jenis adukan sebanyak $(1-5) \%$ dari berat semen. Kode yang digunakan pada benda uji adalah $\mathrm{BI}-0$ untuk adukan tanpa ijuk, $\mathrm{BI}-1$ untuk adukan dengan ijuk $1 \%, \mathrm{BI}-2$ untuk adukan dengan ijuk $2 \%, \mathrm{BI}-3$ untuk adukan dengan ijuk $3 \%$, BI-4 untuk adukan dengan ijuk 4\% dan $\mathrm{Bl}-5$ untuk adukan dengan ijuk $5 \%$.

Penggunaan serat mengakibatkan berkurangnya sifat kemudahan dikerjakan dan mempersulit terjadinya segregasi. Serat dalam beton berguna untuk mencegah adanya retakretak, sehingga menjadikan beton serat lebih daktail daripada beton biasa.

\section{Serat Kasar (Serat Rooving)}

Roving (serat kasar) merupakan serat yang terbuat dari bahan polyester/epoxy, digunakan sebagi media lapisan tengah dari plat fiberglass. Polester merupakan material sintetis yang terbuat dari Purified Terephtalic Acid (PTA) atau dimetil ester Dimethyl Terephthalate (DMT) dan Mono Etilena Glikol (MEG). 


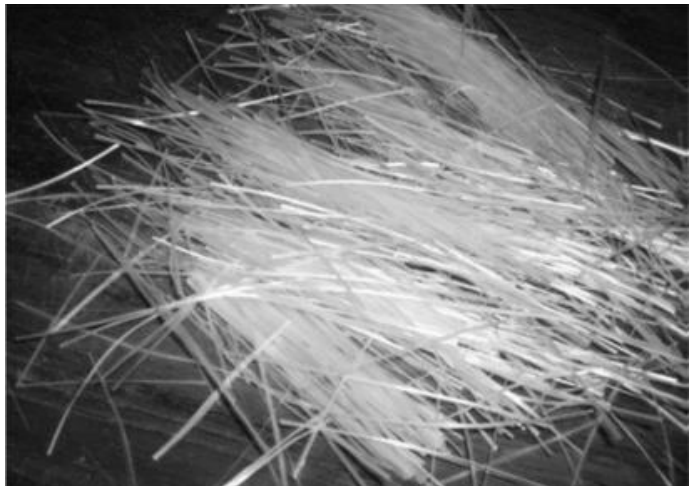

Gambar 3. Bentuk Fisik Serat Roving

Penggunaan serat ini cukup luas sebagai penguat komposit bagian dalam kendaraan atau perahu pesiar dan produk gipsum, sehingga dapat dengan mudah didapatkan. Dalam penelitian Usmanto, dkk (2006) didapatkan hasil pemeriksaan berat jenis roving dari dua sampel yang rata-rata diperoleh berat jenis sebesar $1.364 \mathrm{gram} / \mathrm{cm} 3$.

\section{METODE PENELITIAN}

Metode penelitian yang digunakan dalam penelitian ini adalah metode penelitian eksperimen. Penelitian ini akan mengamati kuat tekan dan kuat tarik belah beton non pasir dengan menambahkan sarat roving sebesar $0 \%, 2,5 \%, 5 \%, 7,5 \%$ dan $10 \%$ dengan perbandingan angregat $1: 5$, dengan FAS 0,4 .

Pengujian yang dilakukan dalam penelitian ini meliputi pengujian agregat kasar, pengujian kuat tekan dan kuat tarik belah beton non pasir dengan ukuran benda uji diameter $15 \mathrm{~cm} \times 30 \mathrm{~cm}$.

Penelitian dilakukan di Laboratorium Jurusan Teknik Sipil, Universitas Negeri Semarang mulai dari pengujian bahan, pembuatan benda uji, perawatan benda uji, dan pengujian benda uji. Kegiatan penelitian dilakukan setelah semua persiapan bahan selesai. Tujuan dari penelitian ini adalah untuk mengetahui besar kadar serat yang dapat dihasilkan kuat tekan dan kuat tarik belah beton non pasir yang optimal. Adapun bagan alir penelitian ada di gambar dibawah ini:

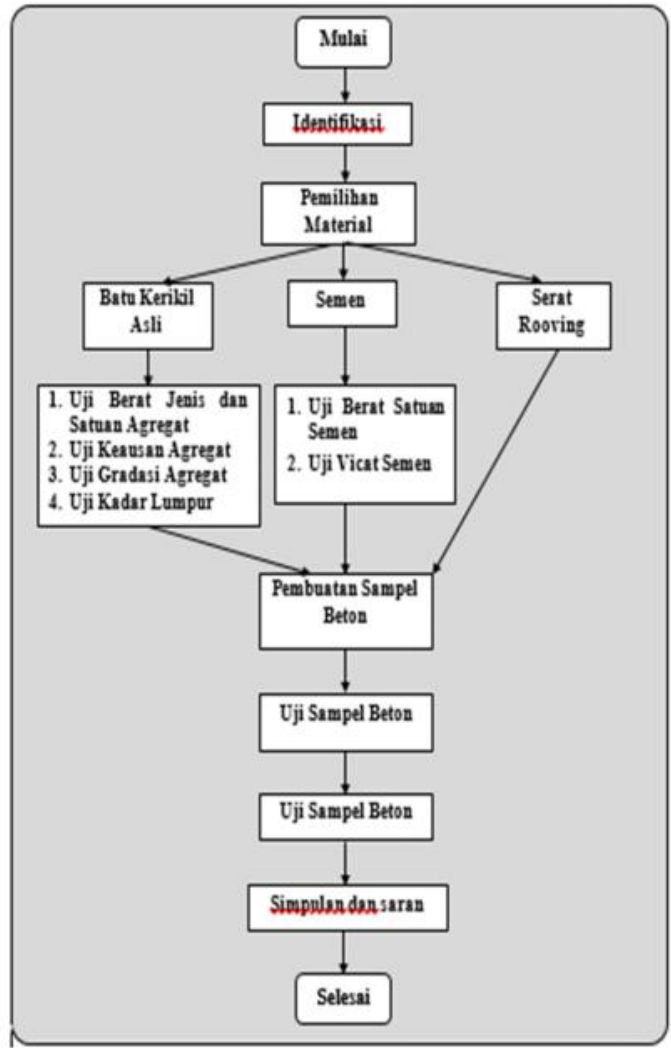

Gambar 4. Bagan Alir Penelitian

Penelitian yang dilakukan adalah dengan membuat sampel benda uji silinder dengan ukuran 15 x $30 \mathrm{~cm}$. Selanjutnya dilakukan perencanaan komposisi campuran untuk mendapatkan komposisi material penyusun beton non pasir. Pembuatan benda uji dilakukan dengan proporsi campuran antara semen dan agregat kasar 1:5 dengan faktor air semen 0,4. Pembuatan benda uji menggunakan agregat kasar berupa kerikil asli dari Sungai Kaligarang dan serat roving sebagai pengganti pasir dalam campuran beton non pasir sebanyak 0\%; 2,5\%; 5\%; 75\% dan $10 \%$ dari berat semen. Kebutuhan material dapat dilihat pada tabel berikut ini.

Tabel 1. Variabel Penelitian

\begin{tabular}{cccccc}
\hline $\begin{array}{c}\text { Komposisi } \\
\text { semen : } \\
\text { agregat }\end{array}$ & $\begin{array}{c}\text { Ukuran } \\
\text { Serat } \\
(\mathrm{cm})\end{array}$ & f.a.s & $\begin{array}{c}\text { Komposisi } \\
\text { serat dari } \\
\text { volume } \\
\text { beton }(\%)\end{array}$ & $\mathrm{f'c}$ & $\mathrm{ft}$ \\
\hline $1: 5$ & $3 \mathrm{~cm}$ & 0,4 & 0 & 3 & 3 \\
\cline { 3 - 5 } & & 2,5 & 3 & 3 \\
\cline { 3 - 5 } & & 5 & 3 & 3 \\
\hline & & 7,5 & 3 & 3 \\
\hline & & 10 & 3 & 3 \\
\hline
\end{tabular}


Setelah benda uji dibuat dan dilakukan perawatan hingga mencapai umur 28 hari. Setelah mencapai umur 28 hari dilakukan uji kuat tekan dan uji permeabilitas terhadap benda uji beton.

\section{HASIL DAN PEMBAHASAN}

Dari hasil pemeriksaan berat jenis agregat kasar, besar berat jenis agregat kasar sebesar 2,33 . Dari hasil pemeriksaan berat jenis agregat kasar diperoleh hasil berat jenis sebesar 2,33 artinya berat jenis agregat kasar berada dibawah berat jenis agregat normal (Agregat Normal ialah agregat yang berat jenisnya antara 2,5 sampai 2,7 menurut Tjokrodimuljo (2007)).

Hasil pengujian berat satuan agregat kasar yang digunakan untuk praktikum diperoleh nilai sebesar 1.572, jadi dilihat dari berat satuannya agregat tersebut dikatakan agregat normal.

Agregat yang peneliti gunakan untuk praktikum adalah berukuran maksimum $20 \mathrm{~mm}$, dari hasil pemeriksaan yang lolos ayakan $19 \mathrm{~mm}$ sebesar $94.5 \%$, kemudian yang lolos ayakan 9,5 $\mathrm{mm}$ sebesar $8,8 \%$, sedangkan yang lolos ayakan 4,75 sebesar 1,67 \%. Jika dibandingkan antara hasil dengan batas-batas gradasi agregat yang digunakan peneliti belum boleh dipakai untuk bahan bangunan steruktur, tetepi dalah penelitian ini digunakan untuk non struktur.

Dari hasil pemeriksaan keausan agregat kasar, sampel 1 menghasilkan keausan sebesar $35,22 \%$, sedangkan sampel 2 sebesar $36,26 \%$, dirata-rata menjadi sebesar 35,74\%.

Dari hasil pemeriksaan, berat satuan sampel untuk semen, sampel 1 didapat sebesar 1095 $\mathrm{kg} / \mathrm{m} 3$, sedangkan sampel 2 didapat sebesar 1105 $\mathrm{kg} / \mathrm{m3}$, dan dirata-rata menjadi $1100 \mathrm{~kg} / \mathrm{m} 3$. Dan untuk uji vicat semen ikatan awal semen terjadi pada menit ke 123 dan ikatan akhir semen terjadi pada menit ke 255 .

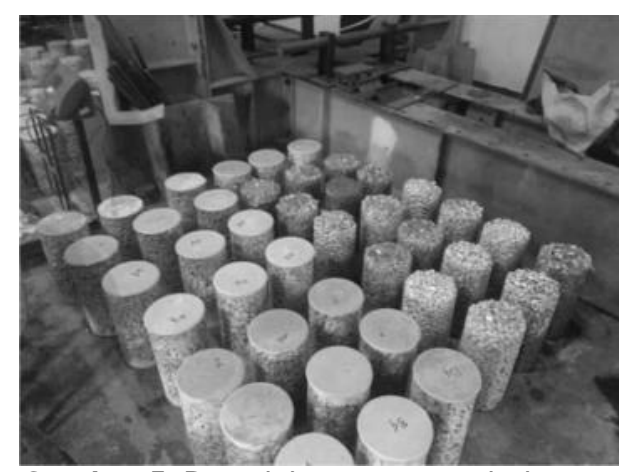

Gambar 5. Bentuk beton non pasir dengan peanambahan serat roving

Pengujian kuat tekan dilakukan setelah beton berusia 28 hari.

Grafik hasil pengujian kuat tekan disajikan dalam gambar berikut:

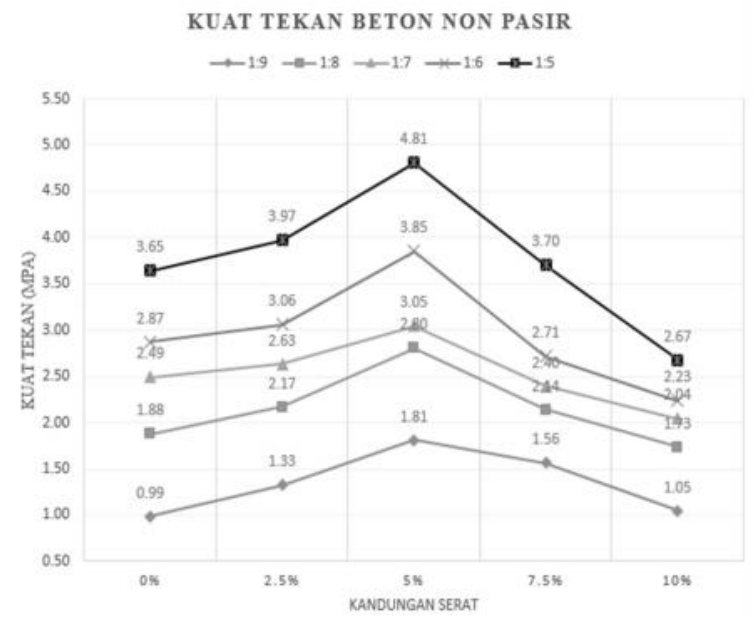

Gambar 6. Kuat Tekan Beton Non Pasir

Dari grafik diatas hasil dari uji kuat tekan mulai naik pada persentase penambahan serat $2.5 \%$, dan mencapai nilai optimum pada penambahan serat $5 \%$,

Nilai kuat tekan menunjukkan bahwa di persentase penambahan serat $5 \%$ yang paling optimal dibandingkan persentase serat yang lain, ini terjadi karena pada penambahan serat sebesar $5 \%$ proporsi bahan pengikat dan bahan pengisi proprsinya optimal atau pas dibandingkan dengan persentase lainnya.

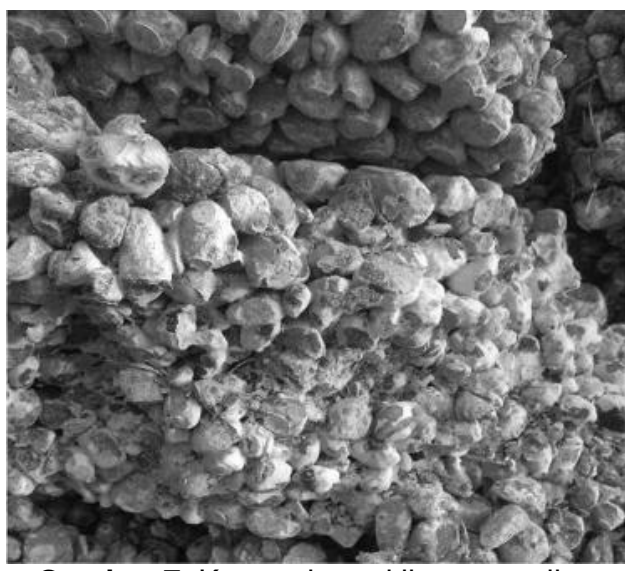

Gambar 7. Keruntuhan akibat pengujian

\section{KESIMPULAN}

Penggunaan serat rooving sebagai pengganti pasir berpengaruh terhadap kuat tekan beton pada setiap perbandingan agregat yang menghasilkan kuat tekan tertinggi pada penggunaan serat roving sebanyak $5 \%$ yaitu sebesar 4,81 MPa pada perbandingan 1:5, sedangkan rata-rata kuat tekan terendah pada setiap perbandingan agregat beton dengan variasi penggunaan serat rooving sebanyak $0 \%$ yaitu sebesar 2,67 MPa pada perbandingan 1:5. 


\section{DAFTAR PUSTAKA}

Apriyatno, Henry. (2007). Pengaruh Penambahan Serat Roving Terhadap Kapasitas Lentur Balok Beton Bertulang. Semarang: Universitas Negeri Semarang.

Fathoni, Abdurrahmat. (2006). Metodologi Penelitian dan Teknik Penyusunan Skripsi. Jakarta: Rineka Cipta.

Mulyono, Tri. (2005). Teknologi Beton. Yogyakarta: Andi.

SK-SNI-T-15-1991-03. Tata Cara Perhitungan Struktur Beton untuk Bangunan Gedung. Bandung: Yayasan LPMB.

SK-SNI-S-04-1989-F. (1989). (Spesifikasi Bahan Bangunan Bagian A)

SNI 15 7064. (2004). Semen Portland Komposit Badan Standart Nasional.

SNI 03-1968-1990. (1990) Metode Pengujian Analisis Saringan Agregat Halus dan Kasar. BSN.

SNI 03-6827-2002. (2002). Metode Pengujian Waktu Ikat Awal Semen Portland dengan Menggunakan Alat Vicat untuk Pekerjaan Sipil. BSN.

Sarjono, Wiryawan. Wahjono, Agt. (2008). Pengaruh Penambahan Serat ljuk Pada Kuat Tarik Campuran Semen-Pasir Dan Kemungkinan Aplikasinya. J umal Teknik Sipil. 8(2).

Tjokrodimuljo, Kardiyono. (2007). Teknologi Beton. Yogyakarta: Biro Penerbit KMTS FT UGM.

Trisnoyuwono, Diarto. (2014). Beton Non Pasir. Yogyakarta: Graha Ilmu.

Usmanto, W. (2006). Pengaruh Penambahan Serat Roving Sebesar $4,48 \%$ dengan Panjang Serat $6 \mathrm{~cm}$ pada Sifat Mekanis Balok Beton Bertulang. Skripsi. Jurusan Teknik Sipil, Fakultas Teknik, Universitas Negeri 